\title{
SUBSTANTIATION OF INNOVATIVE TEACHING METHODS IN TRAINING FUTURE DOCTORS
}

\author{
Natalia Gumeniuk \\ Senior Lecturer, National Pirogov Memorial Medical University, Ukraine \\ e-mail: n.i.gumenyuk.kr@gmail.com, orcid.org/0000-0002-7071-6464
}

Svitlana Khliestova

Associate Professor, National Pirogov Memorial Medical University, Ukraine e-mail: lana231279@gmail.com,orcid.org/0000-0001-7888-2427

\section{Andrzej Kryński}

Professor, Ph.D., Polonia University in Czestochowa, Interdisciplinary Faculty, Poland e-mail: a.krynski@ap.edu.pl,orcid.org/0000-0001-9635-023X

\section{Summary}

The article presents material on solving the problem of improving modern methods and technologies in teaching in medical institutions of higher education, as higher medical education requires rapid changes and non-standard creative solutions, especially in today's conditions. Innovative teaching methods are aimed primarily at the processes of information perception and successful acquisition of practical skills, memory, development of creative and clinical thinking, proficient behavior in extreme situations, and gaining communication experience. The methods are calling innovative because they significantly change both the role of the teacher and the role of students. At the same time, the level of training of future doctors must meet clear criteria of goals and competence approach by the requirements of the quality of education. The importance of innovative teaching methods in the training of future doctors is highlighting. The theoretical and methodological analysis of the educational process of medical institutions of higher education. The content of the application of innovative teaching methods in the training of future doctors is generalized and systematized. Aspects of professional competence of the future doctor are covered. The effectiveness of case studies and situational role-playing methods is substantiated and identified as integral elements of teaching in medical institutions of higher education.

Keywords: students, educational process, professional competencies, professional motivation.

DOI https://doi.org/10.23856/4303

\section{Introduction}

Theoretical principles of training future doctors, which have been focusing on new standards of higher education in European countries through innovative methods in higher education have been basing on the Bologna Process and the European Commission's international project «Harmonization of educational structures in Europe». For medical institutions of higher education in Ukraine, the issue of, the strategy of the national innovative training program for future doctors today is very acute and extremely necessary. Innovative methods in medical institutions of higher education for the training of future doctors - are a new product of the advanced 
technological process, which has been using by teachers in practice to train future doctors capable of independent research, research, innovation in health care institutions, research institutes and other (Gumeniuk et el., 2020).

The main task in the training of future doctors in the development of the European educational process is the training of highly qualified, competent specialists in higher medical education. One of the conditions of competitive higher medical education is the stimulation of clinical thinking in students, the use of interdisciplinary approaches in saturating them with knowledge, skills, abilities (Piskun et el., 2014). Besides, the future doctor must be prepared to systematically process a significant flow of information, to integrate knowledge from new disciplines. Not only programs and curricula but also pedagogical methods and forms of education must meet these requirements.

Therefore, the purpose of our study is to summarize and systematize the importance of innovative teaching methods in the training of future physicians and justify the effectiveness of their use.

Materials and methods were scientific analysis of domestic and foreign sources, content analysis of curricula and plans of medical institutions of higher education, biblio-semantic and descriptive research methods.

\section{Professional competencies of the future doctor}

The introduction of a competency-based approach to higher medical school will solve many problems, one of which is the training of highly qualified, competitive professionals who will be able to make responsible, non-standard decisions and predict their consequences. But it also requires a high level of professional training of teachers, improving their skills, promoting their development, and improving working conditions (Shevchuk et el., 2020).

A doctor who has mastered the professional-oriented activity and the corresponding system of knowledge at the stage of acquiring higher education must study independently with the optimal combination of educational, professional-practical, and scientific activities in the conditions of continuing education (Klishch et el., 2014).

The chief competencies for graduates of higher medical education, which they acquire in the learning process are: integrated - the ability to solve complex problems and problems in the field of health care in the professional activities of future doctors or in the learning process, which involves research; general competencies - the ability of future doctors to abstract thinking, analysis and synthesis; ability to learn and be modernly trained, knowledge and understanding of the subject area and comprehension of the specifics of the profession, the ability to apply knowledge in practical situations; skills in the use of information and communication technologies, the ability to search, process and analyze information from various sources, the ability to adapt and act in a new practical situation; ability to work independently, making responsible decisions following the acquired professional knowledge, skills, and abilities.

Of particular importance are the so-called special (professional, subject) competencies maintaining medical records, processing state, and social information, collecting medical information about the patient's condition, evaluating the results of laboratory and instrumental studies, diagnosing the disease, diagnosing emergencies, performing medical manipulations and, most importantly, the preservation of medical secrecy (Khliestova, 2014).

The quality of doctor's training depends on the professionalism of teachers, the use of modern pedagogical teaching technologies, the involvement of students in research work (student scientific societies, scientific circles), methodological support of educational activities, 
research individual tasks, and projects. Regarding the professionalism of teachers, it is advisable to note the ability to comprehensively influence the formation of all components of professional competence of students using the latest technologies (Morokhovets et. el.,2017).

A modern teacher of higher medical education must demonstrate a high level of knowledge, constantly develop and participate in the implementation of innovative new technologies and methods. It should also create conditions for acquiring knowledge of the basics of health technologies should be an example for future doctors and demonstrate personal and professional growth, professional self-improvement, be an example and teach students to achieve these plans and goals. At the same time, senior teachers studied under different conditions, and it is difficult for such teachers to move and adapt to new innovative teaching methods. A modern teacher of higher education is required to have an interactive approach in the presentation of educational material using modern technologies, innovative didactic approaches, the introduction of simulation tools and practical skills, a comprehensive interdisciplinary approach to solving clinical problems.

The training of future doctors requires from teachers not only practice-oriented technologies but also the mandatory use of innovative technologies in the system of teaching methods, which include not only training but also self-study, development, and improvement of practical skills. The use of innovative teaching methods in the training of future doctors affects the motivation and values of a highly qualified medical professional.

\section{Case method as an integral element of education in medical institutions of higher education}

In the modern pedagogical concept, the case method has been considering to be the most effective innovative method and techniques in the training of future doctors. The case method has been using first in the educational process at the Harvard University of Law in 1870, but this method gained extensive practical significance in 1920. The first collections on the application of these methods were published there. In this direction, foreign researchers have gained experience in both theoretical and practical issues of application of Case study to improve the learning process and knowledge acquisition by students. The following scientists E. Monter, M. Leader, J. Erskin, and others, worked in this direction.

Also, in 2002 our scientists offered the Ukrainian Center for Innovation and Development a fundamental manual, «Situational analysis, or the anatomy of the case method». The works of domestic scientists R. Gurevich, N. Kalashnik, V. Kremen, J. Tsekhmister were devoted to scientific-practical and general-theoretical issues (Hurevych et el., 2019; Skrypnyk et el., 2012).

The case method is a specially prepared material for students, which has been borrowing from an authentic event. To solve this problem, students have been forcing to look for solutions in a specific artificial situation, which allows students to act as a team, or individually. In this situation, students show their knowledge and skills to the extent that they have mastered them.

To form the meta competence of the future doctor in solving the problem in the classroom case method helps to master the material, students conduct a comprehensive analysis of the problem and help to solve similar problems that will arise in professional activities. In the process of modeling team actions in a given problem situation, provides their own beliefs in the acquired skills, which have been practicing in class, as well as allow making the right decision on the situation «Here and now», gives a clear algorithm, gives the chance to substantiate the actions and to convince of the correctness of the actions at the decision of the set task, to critically and constructively estimate the and command actions and mistakes (Kozak, 2015). 
During the students' discussion of the situation, the teacher not only observes but also manages the students' discussion of the task. In the educational process, the teacher takes an active part in the discourse, analysis, or discussion. A great educational and methodological responsibility has been taking by the teacher who prepares the case-task. The created task, in turn, should be of interest to future doctors, and the teacher should monitor the successful or erroneous analysis, make a quick team decision on the task and actively learn skills.

Case methods can be used at any time, both in the learning process and in the control process, to consolidate the material passed. However, there are certain advantages and disadvantages of the case method, the content of which is presenting in table № 1 .

Table 1

\section{Advantages and disadvantages of the case method}

\begin{tabular}{|l|l|}
\hline \multicolumn{1}{|c|}{ The main advantages } & \multicolumn{1}{c|}{ The main disadvantages } \\
\hline $\begin{array}{l}\text { - Ability to identify, analyze and calculate } \\
\text { each step in mastering the theoretical aspects of } \\
\text { the discipline }\end{array}$ & $\begin{array}{l}\text { - In a similar actual situation, a young special- } \\
\text { ist without the support of the group is unlikely } \\
\text { to be able to recall the experience quickly. }\end{array}$ \\
\hline $\begin{array}{l}\text { - A unique opportunity is creating to study } \\
\text { complex professional issues in an emotionally } \\
\text { favorable atmosphere of the educational process. }\end{array}$ & $\begin{array}{l}\text { - Time constraints may not allow the group to } \\
\text { develop objective and effective ways to solve } \\
\text { the task. This can lead to dissatisfaction with } \\
\text { the method. }\end{array}$ \\
\hline $\begin{array}{l}\text { - The communicative nature of the method } \\
\text { provides an opportunity, with the appropri- } \\
\text { ate knowledge, to make a quick but thorough } \\
\begin{array}{l}\text { assessment of the issues to be studied and the } \\
\text { proposed solutions. }\end{array}\end{array}$ & $\begin{array}{l}\text { Low student activity leads to a decrease in } \\
\text { feel uncomfortable if they do not feel supported } \\
\text { by a teacher or classmates. }\end{array}$ \\
\hline
\end{tabular}

At the same time with the help of case tasks, future doctors develop analytical, communicative, social, creative, practical skills of each lesson, and gain extensive experience, identify, and develop their personal qualities most importantly master the ability to work in a team or small groups the ability to identify the main task, and in their actions. After such classes in the following practical categories by future doctors, it is observing that they are faster and more accurate to assess the following situations, more responsibly choose the best solution, more grouped, balanced, listen to all options of their team.

\section{Methodical principles of situational role-playing game}

In recent years, the method of situational role-playing has been widely using in the teaching field of medical institutions of higher education. The theoretical basis of this method is the position of the crucial role of active, specially organized activities of students in the process of acquiring practical knowledge and skills. The expediency of using active methods is consistent with the data of experimental psychology, according to which $10 \%$ of the material received by the ear, $50 \%$ of the material seen, and $90 \%$ of what students perform independently.

The essence of the method of situational role-playing is improvised role-playing that simulates a typical clinical situation. The game involves a group of students who perform tasks provided by the script. The identical circumstances can be playing several times to allow game participants to play themselves in different roles. There are numerous modifications of situational games using non-identical techniques. One of the varieties is basketball - a method in 
which most students have been involved at the same time some act as victims, others as rescuers or doctors of emergency medical teams (EMT). The situation modeled in the role play should be as close as possible to reality (Averchenko et el., 2013).

The chief point of the situational role-playing game is an accurately developed scenario for it and an understandable sequence of actions in assisting victims and patients at the pre-hospital stage, which should have been recording in the checklist grown for each task. The proposed clinical situation should include the plot of the role-play; a clear clinical problem; the nature of the given situation and the conditions of its implementation; clear distribution of roles and consistent execution of help algorithms.

Therefore, during the preparation of a situational role-playing game, the teacher must anticipate all possible ramifications of the initial situation, must always be ready to provide students involved in the game information about changes in the patient's or victim's condition due to actual actions of students during the game. Directly during the execution of help algorithms to correct striking mistakes so that the skill to be mastered has been not fixing incorrectly. Therefore, the preparation of methodological support for situational role-playing is a very complex and time-consuming organizational work. During the devising of the game, it is difficult to predict all possible actions of students (Volkova et el., 2018).

Therefore, the purpose of situational role-playing is the most important - the formation of cognitive and professional motivations, systematic clinical thinking of the future doctor, teamwork and independent decision-making skills, teamwork and interaction skills.

Table № 2

Characteristics of stages and content of the situational role-playing game

\begin{tabular}{|l|l|l|}
\hline \multicolumn{1}{|c|}{$\begin{array}{c}\text { No The stage } \\
\text { of the game }\end{array}$} & \multicolumn{1}{c|}{$\begin{array}{c}\text { Name the stage } \\
\text { of the game }\end{array}$} & \multicolumn{1}{c|}{ The content of the game stage } \\
\hline $\begin{array}{l}\text { I stage of situational } \\
\text { role-playing game }\end{array}$ & $\begin{array}{l}\text { Introducing students } \\
\text { to the source informa- } \\
\text { tion }\end{array}$ & $\begin{array}{l}\text { - presentation of source information by the } \\
\text { teacher; } \\
\text { joint definition of game tasks and educational } \\
\text { tasks; } \\
\text { - distribution of roles among students }\end{array}$ \\
\hline $\begin{array}{l}\text { II stage of situational } \\
\text { role-playing game }\end{array}$ & $\begin{array}{l}\text { Preparing students for } \\
\text { role play }\end{array}$ & $\begin{array}{l}\text { analysis of source information; } \\
\text { study of theoretical issues and basic algo- } \\
\text { rithms of assistance on the topic of the lesson; } \\
\text { - preparation for role functions }\end{array}$ \\
\hline $\begin{array}{l}\text { III stage of situational } \\
\text { role-playing game }\end{array}$ & Conducting a role play & $\begin{array}{l}\text { performance of role functions by participants; } \\
\text { game management, teacher control over com- } \\
\text { pliance with the rules of assistance; } \\
\text { reflection, analysis of game results; } \\
\text { - summarizing the game by the teacher. }\end{array}$ \\
\hline
\end{tabular}

Analysis of the effectiveness of situational role play in achieving goals and providing feedback between student and teacher is chief and necessary in a better understanding of the clinical situation in the proposed task and helps to understand actions in an extreme situation.

The effectiveness of situational role-playing in the training of future doctors is that it helps to objectively assess the preparation of the student for the lesson; transparency in knowledge assessment; develops skills of public speaking and work in simulated extreme situations; develops the ability to formulate an opinion using professional terms; situational role 
play reduces the time of accumulation of professional experience; development and formation of professional competencies and works both in a team and independent decision-making. An example of the use of situational role-playing in the learning process is presenting in Fig. 1.

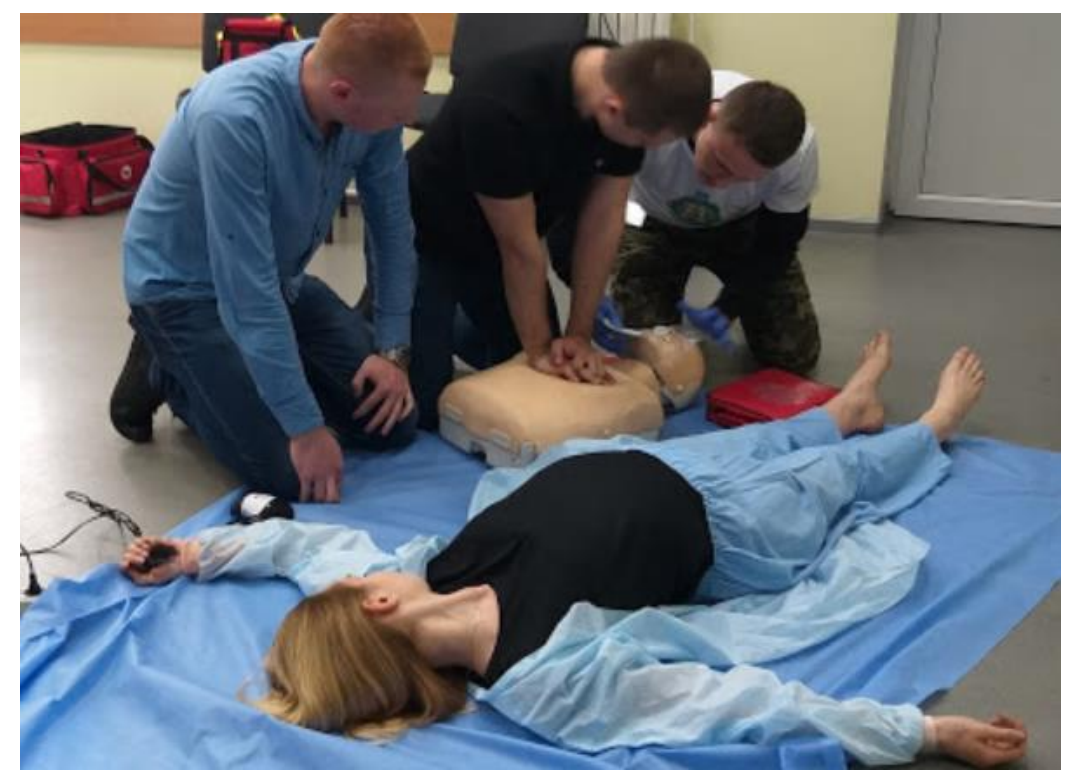

Fig. 1. Situational role-play with students and a mannequin

Thus, situational-role (positional) games solve mainly the problem of forming the communicative component of the professional activity of future doctors, determining an active position in acquiring professional competencies, devising stereotypes of professional behavior and its correction in communication with victims, patients, their relatives, and colleagues.

\section{Conclusions}

Thus, analyzing scientific domestic and foreign sources, we can conclude that the chief vector of development of modern higher education in Ukraine medical profile is determining by the general focus on the process of entering domestic higher education in the European and world educational space. The introduction of innovative teaching methods in the training of future doctors is a priority of the concept of reforming and modernizing the instruction of medical students in creating an unconventional educational environment in higher education institutions through the promotion of progressive innovations. The application of a wide range and the introduction of innovative teaching methods should become one of the hallmarks of modern approaches in the teaching of professional disciplines. The conducted theoretical and methodological analysis gives grounds to determine further prospects for the effectiveness of innovative teaching methods in the training of future doctors and practically check in the course of the further experiment the feasibility of implementation. 


\section{References}

Averchenko, L.K., Doronina, I.V., Ivanova, L.N. (2013). Imitaczionnaya delovaya igra kak metod razvitiya profesional nykh kompetenczij [Imitation business game as a method of developing professional competencies]. Vy`sshee obrazovanie segodnya. 10, 35-39. [in Russia] Volkova, N.P., Stepanova, A.A. (2018). Fasilitator yak vazhliva rol ’ova pozicziya suchasnogo vikladacha vishu [Facilitator as an important role position of a modern university teacher]. Visnik universitetu imeni A. Nobelya. 1(15), 228-234. [in Ukrainian]

Gumenyuk, N.I., Romanovska, O.O., Matvijchuk, M. V., Korolova, N.D., Chorna, V.V. ta in. (2020). Otsinka aktualnosti zastosuvannia innovatsiinykh metodiv navchannia $v$ umovakh dystantsiinoi osvity [Assessment of the relevance of the application of innovative teaching methods in the context of distance education]. Visnyk Vinnytskoho natsionalnoho medychnoho universytetu, vol. 24, no. 2, pp. 292-296 https://doi.org/10.31393/reports-vnmedical-2020-24(2)-16 Hurevych, R.S., Tsekhmister, Ya.V., Kalashnik, N.V., Kobernyk, O.M., Lysenko, O.Yu. (2019). Formuvannia profesiinoi etyky maibutnikh likariv-khirurhiv zasobamy tekhnolohii «keisstadi» [Formation of professional ethics of future surgeons by means of "case study» technology]. Klinichna khirurhiia. 86(7): 63-67 DOI: https://doi.org/10.26779/2522-1396.2019.07.63 Klishch, H.I., Fedchyshyn, N.O., Yelahina, N.I. (2014). Samostiina robota studenta medyka yak zasib formuvannia inshomovnykh vmin i navychok [Independent work of a medical student as a means of forming foreign language skills]. Medychna osvita. 1, 35-40. [in Ukrainian]

Kozak, L.V. (2015). Keis-metod u pidhotovtsi maibutnikh vykladachiv do inovatsiinoi profesiinoi diialnosti [Case-method in preparing future teachers for innovative professional activities]. Osvitolohichnyi dyskurs. 3(11), 153-162. [in Ukrainian]

Morokhovets, H., Makarenko, O., Stetsenko, S. (2017). Formuvannia profesiinoi kompetentnosti maibutonoho likaria yak pedahohichna problema [Formation of professional competence of the future doctor as a pedagogical problem]. Vytoky pedahohichnoi maisternosti. 20, 183-187. [in Ukrainian] Piskun, R.P., Hrynchak, N.M., Shkarupa, V.M., Sprut O.V., Khliestova, S.S. Formuvannia klinichnoho myslennia ta profesiinykh kompetentnostei yak odyn z priorytetnykh napriamkiv vyshchoi medychnoi osvity [Formation of clinical thinking and professional competencies as one of the priority areas of higher medical education]. Humanitarnyi visnyk DVNZ «Pereiaslav-Khmelnytskyi derzhavnyi pedahohichnyi universytet imeni Hryhoriia Skovorody»Dodatok 1 do Vyp. 5, Tom V (56): Tematychnyi vypusk «Vyshcha osvita Ukrainy u konteksti intehratsii do yevropeiskoho osvitnoho prostoru». - K.: Hnozys, - S. 352-360. [in Ukrainian] Skrypnyk, I.M., Sorokina, S.I., Shevchenko, T.I., Kudria, I.P., Shaposhnyk, O.A. (2012). Keismetod yak pryklad interaktyvnoho navchannia studentiv-medykiv klinichnym dystsyplinam [Case method as an example of interactive teaching of medical students in clinical disciplines]. Mizhnarodni Chelpanivski psykholoho-pedahohichni chytannia. 1 (1), 372-378. [in Ukrainian] Khliestova S.S. (2014). Vyznachennia hotovnosti maibutnikh likariv do vykonannia svoho profesiinoho oboviazku pid chas navchannia $v$ universyteti [Determining the readiness of future doctors to perform their professional duties while studying at the university]. Naukovi zapysky Vinnytskoho derzhavnoho pedahohichnoho universytetu imeni Mykhaila Kotsiubynskoho : zb. nauk. pr. ; [za red. V. I. Shakhova]. Vypusk 41. Vinnytsia : Planer, pp. 278-282. (Seriia: Pedahohika i psykholohiia). [in Ukrainian] Shevchuk, T.I., Khliestova, S.S. (2020). Naukovo-teoretychni osnovy formuvannia sotsiokomunikatyvnoi kompetentnosti maibutnikh likariv u protsesi vyvchennia pryrodnychykh dystsyplin [Scientific and theoretical bases of formation of sociocommunicative competence of future doctors in the process of studying natural sciences]. Vyklyky ta dosiahnennia medychnoi nauky ta osvity: Kolektyvna monohrafiia. Ryha, Latviia: «Baltija Publishing», 430 p. https://doi.org/10.30525/978-9934-26-024-7-20 